\title{
ARTIKKELIT
}

\section{Muistisairas ihminen liikenteessä}

\author{
Henna Nikumaa ${ }^{1}$, Anna Mäki-Petäjä-Leinonen ${ }^{2}$ \\ ${ }^{1}$ Helsingin yliopisto, ${ }^{2}$ Itä-Suomen yliopisto
}

\begin{abstract}
Ikääntyvien kuljettajien määrän lisääntyessä myös muistisairaiden ihmisten osuus ajokortin haltijoissa kasvaa. Artikkelissa tarkastellaan etenevää muistisairautta sairastavan ihmisen ajo-oikeutta hyödyntäen lainopin menetelmiä. Vaikka muistisairaus johtaa edetessään ajokortista luopumiseen, ei pelkkä diagnoosi sairauden lievässä vaiheessa tarkoita ajoluvan menettämistä kaikissa ajokorttiryhmissä. Onnettomuusriski kasvaa sairauden edetessä, mutta yksilölliset erot voivat olla merkittäviä, ja ajokyvyn arvioinnissa tulee kiinnittää huomiota muistisairaan kokonaistilanteeseen. Oikeus ajoneuvon kuljettamiseen on usein keskeinen osa sairastuneen identiteettiä ja osa hänen autonomiansa toteutumista. Ajo-oikeuden poistaminen voi kuitenkin olla välttämätöntä paitsi sairastuneen itsensä suojaamiseksi myös muiden turvallisuuden takaamiseksi. Artikkelin lopuksi pohditaan ratkaisuja muistisairaan ihmisen liikkumisen turvaamiseksi. Tutustuminen vaihtoehtoisiin ja turvallisiin liikkumisen keinoihin tulisi aloittaa riittävän ajoissa. Rajoitetun ajo-oikeuden mahdollisuutta tulisi edelleen maassamme selvittää erityisesti syrjäseuduilla asuvien varhaisvaiheen muistisairaiden näkökulmasta. Lisäksi muistisairaille ihmisille tulee taata muiden sairaus- ja vammaryhmien tavoin yhdenvertainen oikeus vammaispalvelulain nojalla myönnettäviin kuljetuspalveluihin.
\end{abstract}

\section{Johdanto}

Ikääntyvillä ihmisillä toimintakyvyn muutokset ovat yleisiä, ja ikääntyneiden ajokyvystä on keskusteltu viime vuosina vilkkaasti. Vaikka jalan ja polkupyörällä kulkevan iäkkään onnettomuusriski on kohonnut (OTI-vuosiraportti 2015), ovat iäkkäät ihmiset turvallisia autoilijoita (Dellinger, Kresnow, White \& Sehgal 2004; Evans 2000; Lafont, Gabaude, Paire-Ficout \& Fabrigoule 2010). Liikenneonnettomuuksista vain neljä prosenttia on yli 70 -vuotiaiden aiheuttamia. Varsinkin juuri ajokortin saaneisiin kuljettajiin verrattuna ikääntyneet kuljettajat pärjäävät liikenteessä hyvin. Vahingoitta tai rikkomuksitta selviää vuoden aikana 88 prosenttia yli 65-vuotiaista kuljettajista. Vastaava osuus nuorilla kuljettajilla on 58 prosenttia. (Mikkonen 2010.) Vaikka iäkkäät ihmiset tarvitsevat enemmän aikaa havaitsemiseen ja heidän rektionopeutensa hidastuu, ovat iäkkäät kuitenkin monessa suhteessa turvallisempia kuljettajia kuin keskivertoautoilijat. Iäkkäät autoilijat keskimäärin eivät ota turhia riskejä tai syyllisty ylinopeuteen tai rattijuopumukseen (Partinen \& Sainio 2015), ja luonnollisesti he ovat usein myös kokeneita, kun heitä verrataan nuorempiin kuljettajiin. 
Suuret ikäluokat vanhenevat, keskimääräinen elinikä pitenee, ja tulevaisuudessa ajokortti on yhä useammalla ikääntyneellä ihmisellä. Tilastojen valossa tämä on jo nyt nähtävillä. Vuonna 2011 Suomessa oli 300000 yli 70-vuotiasta ajokortin haltijaa, kun tuo luku vuonna 1990 oli vain 70000 . Iäkkäiden kuljettajien osuus lisääntyy edelleen, ja vuonna 2030 arvioidaan joka kolmannen ajokortin haltijan olevan yli 70-vuotias (Mikkonen 2014). Kalenojan, Tiikkajan ja Kallbergin (2008) mukaan suurimmat muutokset tapahtuvat kuitenkin yli 84-vuotiaiden ryhmässä. Vuonna 2007 yli 84-vuotiaita ajokortin haltijoita oli 7000 ja vuonna 2040 heitä ennustetaan olevan 50000 . Ikääntyvistä kuljettajista 90 prosenttia kertoo luopuvansa kortistaan vasta, kun se on terveydentilan kannalta tarpeellista (Kalenoja \& Tuominen 2016).

Väestön ikääntyessä myös muistisairaiden ihmisten määrä kasvaa. On siis todennäköistä, että tulevaisuudessa yhä useampi ikääntynyt kuljettaja joutuu luopumaan ajokortistaan etenevän muistisairauden vuoksi. Etenevät muistisairaudet ovat merkittävin ikääntyneiden pitkäaikaista avuntarvetta aiheuttava sairausryhmä. Vuonna 2013 arvioitiin Suomessa olleen 93000 keskivaikeaa tai vaikeaa muistisairautta sairastavaa ihmistä. Vuonna 2060 heitä arvioidaan olevan 240000 (Gardner, Valcour \& Yaffe 2013; Viramo \& Sulkava 2015). Samalla on myös huomioitava, että etenevät muistisairaudet eivät ole pelkästään ikääntyvien ihmisten sairauksia. Työikäisenä muistisairauteen sairastuneita ihmisiä arvioidaan olevan maassamme noin 7000 (Käypä hoito -suositus 2017).

Tarkastelemme tässä artikkelissa etenevää muistisairautta sairastavan ihmisen ajo-oikeutta hyödyntäen lainopillisia ja de lege ferenda -tutkimuksen menetelmiä (Siltala 2003) aihettamme kriittisesti reflektoiden (Fook 2004; Mezirow 1998). Artikkeli jäsentyy seuraavasti: Artikkelin taustaksi kuvaamme muistisairauden vaikutuksia yksilön ajokykyyn, esittelemme keskeisen ajokorttilainsäädännön ikääntyvien ja muistisairaiden näkökulmasta sekä tarkastelemme muistisairaan ihmisen ajokyvyn arviointia ja sen haasteita. Tämän jälkeen pohdimme ajokortin haltijan autonomiaa ja ajokortin merkitystä muistisairaalle ihmiselle. Artikkelin lopuksi tarkastelemme erilaisia liikkumisen vaihtoehtoja ja pohdimme ratkaisuja muistisairaan ihmisen liikkumisen turvaamiseen.

\section{Etenevät muistisairaudet ja niiden vaikutukset ajokykyyn}

Muistisairaus ei nykyisen tutkimustiedon perusteella kuulu normaaliin ikääntymiseen (ks. esim. Dubois \& Albert 2004; Ferri ym. 2005). Muistisairaudella tarkoitetaan etenevää neurologista sairautta, joka heikentää sekä muistia että muita tiedonkäsittelyn osa-alueita. Sairaus heikentää kielellisiä toimintoja, näönvaraista hahmottamista ja toiminnanohjausta. Asioiden sujuva suorittaminen vaikeutuu, ja sairauden edetessä monivaiheisten asioiden tekeminen hankaloituu ja rajoittaa henkilön itsenäistä selviämistä (Erkinjuntti, Remes, Rinne \& Soininen 2015). On mahdollista, että muistisairas ihminen ei itse tunnista näitä haasteitaan. Muistisairauksissa kognitiiviset oireet eroavat toisistaan, mutta puutteellinen oiretiedostus on tavallista sekä epärealistinen näkemys omista kyvyistä, kuten esimerkiksi ajokyvystä tai kyvystä tehdä päteviä oikeustoimia (Löppönen \& Ojala 2017; Mäki-Petäjä-Leinonen 2013).

Aistitoiminnot ja tarkkaavaisuus ovat yksilön ajokyvyn kannalta merkityksellisiä. Nämä ominaisuudet heikentyvät ikääntyessä myös ilman merkittäviä sairauksia (Partinen \& Sainio 2015), mutta erityisesti ne heikentyvät muistisairauteen sairastuneilla (ks. esim. Breen, Breen, Moore, Breen \& O’Neill 2007; Dubinsky, Stein \& Lyons 2000; Iverson ym. 2010; Ott ym. 2008). Etenevät muistisairaudet aiheuttavat kuljettajalle tiedonkäsittelyyn liittyviä haasteita ja tarkkaavuuden häiriöitä, arviointivirheitä, kätevyyden vaikeutta, sekavuutta ja väsymystä. Myös aistitoiminnot heikentyvät, tiedonkäsittely ja reaktionopeus hidastuvat, ja 
motoriikassa havaitaan vaikeuksia (Partinen $\&$ Sainio 2015).

Muistisairaudet johtavat edetessään dementiaan. Muistisairauksia on useita, ja ne ovat oireiltaan ja etenemiseltään erilaisia. Alzheimerin tauti on tavallisin muistisairaus. Sitä sairastaa 65-70 prosenttia kaikista muistisairaista ihmisistä (Viramo \& Sulkava 2015). Noin viidesosalla muistisairaista on vaskulaarinen kognitiivinen heikentymä, joka on seurausta aivoverenkiertohäiriöistä. Muita dementiaan johtavia syitä ovat muun ohella eräät rappeuttavat aivosairaudet, kuten Lewyn kappale -tauti (10$15 \%)$ ja niin sanotut otsa-ohimolohkorappeumat (alle $5 \%$ ) sekä tulehdukset, aivovammojen jälkitilat ja alkoholismi. (Aarsland, Zaccai \& Brayne 2005; Emre, Aarsland \& Brown 2007.) Erilaisten muistisairauksien erojen ymmärtäminen on tärkeää, sillä kaikki muistisairaudet eivät aiheuta samantasoista riskiä ajamiselle (Hoffman Snyder 2005).

Muistisairaan ihmisen ajotaidot heikentyvät sairauden edetessä. Muistisairauden vaikeusastetta kuvataan jakamalla sairauden kulku lievään, keskivaikeaan ja vaikeaan vaiheeseen. Lievässä vaiheessa etenevää muistisairautta sairastava henkilö selviää arjesta satunnaisen ohjauksen ja tuen avulla, keskivaikeassa vaiheessa hän tarvitsee säännöllistä ohjausta, ja vaikeassa vaiheessa hän tarvitsee apua jatkuvasti (Alhainen 2001). Päivittäisissä toiminnoissa selviäminen korreloi ajokyvyn kanssa: arjen askareiden vaikeutuessa heikentyy usein myös ajokyky. Partisen ja Sainion (2015) mukaan ajokykyä on kuitenkin arvioitava yksilöllisesti erityisesti lievässä muistisairauden vaiheessa, jolloin sairauden vaikeusaste ei aina suoraan korreloi ajotaidon kanssa. Kuikan, Summalan, Kalakosken ja Sallisen (2012) mukaan ajokyvyn arvioinnin kannalta voi olla merkityksellistä, että yksilöllinen niin sanottu kognitiivinen reservi voi hidastaa toimintakyvyn heikkouksien ilmenemistä. On myös todettu, että vaikka lievää muistisairautta sairastavat ihmiset kuuluvat riskialttiiden kuljettajien ryhmään, heistä lähes 80 prosenttia kykenee edelleen ajamaan turvallisesti. Keskivaikeassa ja vaikeassa muistisairaudessa liikenneonnettomuusriski on kuitenkin selvästi suurentunut (Brown ym. 2005; Grace ym. 2005; Ott ym. 2008).

Vaikka onnettomuusriskiä on yksilötasolla vaikeaa arvioida, on tutkimuksissa todettu, että esimerkiksi Alzheimerin tautia sairastavilla henkilöillä onnettomuusriski kasvaa tilastollisella tasolla vuosittain. Drachmanin ja Swearerin (1993) mukaan kuitenkin vielä viidentenä vuonna diagnoosin saamisen jälkeen riskiluvut Alzheimerin tautia sairastavilla ihmisillä jäivät selvästi alle 16-24 -vuotiaiden miesten onnettomuusriskiluvun. Toisaalta riskiluvuissa on otettava huomioon iäkkäiden ihmisten yleinen maltillinen ajotapa. Breenin ym. (2007) laajan kirjallisuuskatsauksen mukaan onnettomuusriski säilyy huomattavan alhaisena kolme vuotta muistisairauden alkamisesta. Tähän mennessä suurin osa muistisairasta ihmisistä on jo luopunut ajamisesta. Myös varhainen diagnostiikka vaikuttaa muistisairauksiin liittyvään onnettomuusriskiin. Meulenersin, Ng:n, Chown \& Stevensonin (2016) mukaan muistisairauteen sairastuneista 43 prosenttia oli ollut kuljettajana auto-onnettomuudessa diagnoosia edeltävien kolmen vuoden aikana, kun verrokeista onnettomuuden oli ajanut 30 prosenttia. Diagnoosia seuraavien kolmen vuoden aikana muistisairaiden onnettomuusriski kuitenkin putosi 93 prosenttia.

Muistisairaiden ihmisten onnettomuusriskiä tarkasteltaessa on myös huomioitava, että suurin osa aihetta käsittelevistä tutkimuksista on koskenut Alzheimerin tautia sairastavia henkilöitä - muita muistisairauksia sairastavien osuus on ollut tutkimuksissa vähäinen (ks. esim. Breen ym. 2007). Kuten edellä on todettu, muistisairauksia on useita, ja ne ovat oireiltaan ja etenemiseltään erilaisia. Myös yksilölliset erot voivat olla merkittäviä, mikä on huomioitava onnettomuusriskilukujen tulkinnoissa. 


\section{Ikääntyneet ja muistisairaat ihmiset ajokorttilainsäädännössä}

Viimeisen viiden vuoden aikana maamme ajokorttilainsäädäntö sekä ajoterveyteen liittyvät ohjeet ja käytännöt ovat muuttuneet. Ajokorttilainsäädäntö uudistui vuonna 2013, jolloin uusi ajokorttilaki (386/2011) tuli voimaan. Kysymyksessä oleva laki perustuu EU:n kolmanteen ajokorttidirektiiviin (2006/126/EY). Ajokorttilaissa ajoneuvojen kuljettajat luokitellaan kahteen ryhmään (4 §). Ryhmään 1 kuuluvat moottoripyörän, henkilöauton, pakettiauton sekä henkilöautovetoisen yhdistelmän kuljettajat ja traktorin ja mopon kuljettajat. Ryhmään 2 kuuluvat kuorma-auton, linja-auton ja niiden yhdistelmien sekä ammattiajoluvan kuljettajat.

Euroopassa ajoterveysvaatimusten seurannassa on käytössä pääsääntöisesti kaksi eri järjestelmää. Ryhmän 1 ajokorttia haettaessa vaaditaan joko lääkärintodistus tai terveydentilaa koskeva henkilön oma ilmoitus tai vakuutus. Ryhmän 2 ajokorttia haettaessa vaaditaan lääkärintodistus. (Siren \& Haustein 2015; Löytty 2016.) Suomessa kaikilta ajokorttiluvan hakijoilta vaaditaan lääkärinlausunto tai voimassa oleva nuorison terveystodistus. Lisäksi lupahakemukseen on liitettävä erikoislääkärinlausunto, jos sellainen on esitetyn läkärinlausunnon tai muutoin Liikenteen turvallisuusviraston (Trafi) tietoon tulleen syyn vuoksi tarpeen hakemuksen käsittelemiseksi (AjokorttiL 10 §). Ajokorttilain 17 ja 18 §:ssä säädetään ajokorttiluvan edellytyksenä olevista terveysvaatimuksista ryhmien 1 ja 2 osalta. Nämä vaatimukset liittyvät muun ohella näöntarkkuuteen ja näkökenttään. Molempien ryhmien terveysvaatimusten osalta vaaditaan lisäksi, että hakijalla ei ole sellaista ajokorttidirektiivin liitteessä III mainittua vikaa, sairautta tai vammaa, joka olennaisesti heikentää hänen kykyään toimia ajoneuvon kuljettajana, tai jos hänellä on ajokykyyn vaikuttava vika, sairaus tai vamma, se ei heikennä olennaisesti hänen kykyään toimia automaattivaihteisen tai alkolukolla taikka eri- tyisin ajohallintalaittein varustetun ajoneuvon kuljettajana.

Ajokorttilaissa ei luetella erilaisia ajokykyyn vaikuttavia sairauksia tai vammoja vaan viitataan ajokorttidirektiivin liitteeseen III, jossa määritellään moottoriajoneuvon kuljettamiseen vaadittavaa fyysistä ja henkistä suorituskykyä koskevat vähimmäisvaatimukset. Neurologiset sairaudet, joihin etenevät muistisairaudet kuuluvat, on liitteessä mainittu omana kohtanaan (kohdat 11-12). Esimerkiksi ryhmän 1 ajokorttia ei saa uudistaa sellaisille kuljettajille, jotka sairastavat vakavaa neurologista sairautta, ellei hakemuksen tueksi esitetä puoltavaa lausuntoa (liite III, kohta 11). Kyseisissä kohdissa ei varsinaisesti nimetä muita neurologisia sairauksia kuin epilepsia (kohta 12), vaikka nimenomaan muistisairaudet ovat määrällisesti suurin neurologisten sairauksien ryhmä. Sen sijaan vanhenemiseen liittyvät käytös- ja persoonallisuushäiriöt on kirjattu ajokorttidirektiivin liitteessä III psyykkisiin häiriöihin (kohta 13). Trafin (2016) ajoterveyden arviointiohjeissa lääkäreille muistisairaudet on määritelty neurologisten, ei psyykkisten sairauksien alle.

Edellä mainittujen terveysvaatimusten lisäksi iäkkäiden kuljettajien on tullut vuodesta 2013 lähtien käydä niin kutsutussa laajennetussa lääkärintarkastuksessa ajokorttia varten, sillä aiempia terveystarkastuksia iäkkäiden ajokyvyn selvittämiseksi ei pidetty riittävinä (HE 212/2010). Ajokorttilain 27 §:n mukaan tarkastus tulee ensimmäisen kerran tehtäväksi, kun ajokortin uusija täyttää 70 vuotta tai sellaista ajokorttia uusittaessa, joka on annettu hakijalle enintään viideksi vuodeksi 70 ikävuodesta lukien tai mainituksi ajaksi syystä, että hakija on täyttänyt 65 vuotta. Ryhmän 2 luokkien osalta laajennettu terveystarkastus tulee tehdä 70 ikävuodesta lukien ja silloin, jos ajokortti annetaan enintään kahdeksi vuodeksi syystä, että henkilö on täyttänyt 68 vuotta. Vuoden 2016 alussa Trafi antoi ajoterveyden arviointiohjeen lääkäreille, jossa ohjeistetaan myös laajennetun ajoterveystarkastuksen tekemiseen iäkkäälle. Laajennetussa lääkärintar- 
kastuksessa kiinnitetään huomiota erityisesti siihen, miten ikääntyminen, sairaudet ja lääkkeet vaikuttavat aistitoimintoihin, tiedonkäsittelyyn ja motorisiin toimintoihin.

Vaikka ajoterveyttä pidetään tärkeänä vaatimuksena ajoluvalle, ei kaikkiin ajo-oikeuden haltijoihin kohdistuvia ikäkausitarkastuksia pidetä välttämättä järkevinä. Ikäkausitarkastukset ovat käytössä suurimmassa osassa EU-maita,ja niiden hyötyjä on tutkittu laajalti (HakamiesBlomqvist, Johansson \& Lundberg 1996; Mitchell 2008; Siren \& Meng 2012). Yleisesti tutkimuksissa on tultu johtopäätökseen, että ikään perustuva seulonta ei lisää liikenneturvallisuutta, ja esimerkiksi Hollannin tieturvallisuusinstituutin (SWOV) tutkimuksen lopputulemana ikään perustuvista tarkastuksista suositeltiin luovuttavan kokonaan (Vlakveld \& Davidse 2011).

Sirenin ja Hausteinin (2015) katsauksen mukaan tosin joillekin yksittäisille toimenpiteille, kuten näkökyvyn testaamiselle ja rajoitetulle ajo-oikeudelle, on löydetty positiivisia turvallisuusvaikutuksia. Samalla on kuitenkin todettu, että ikään perustuvilla ajoterveystarkastuksilla voi olla jopa negatiivinen yhteys ikääntyneiden kuljettajien ajoturvallisuuteen (Martensen \& Diependale 2014; Mikkonen 2014). Ikääntyneet ihmiset, jotka ovat luopuneet ajokortistaan, siirtyvät lisäksi usein heille turvattomampiin liikennemuotoihin, kuten jalankulkijoiksi tai polkupyöräilijöiksi. Tämä voi vaikuttaa negatiivisesti ikääntyneen turvallisuuteen erityisesti silloin, kun yleinen infrastruktuuri ei tue heidän liikkumismahdollisuuksiaan (Siren \& Haustein 2015). Tutkimustieto suositteleekin, että sekä turvallisuuden että kustannustehokkuuden näkökulmasta painopistettä tulisi siirtää riski-kuljettajien tunnistamisesta ikääntyneiden turvallisen ajamisen tukemiseen (Siren \& Meng 2012).

Mielenkiintoinen on myös havainto, jonka mukaan maissa, joissa ryhmän 1 ajokorttiluokissa on ikään perustuvien ajoterveystarkastusten sijaan käytössä itseilmoitus, tapahtuu vähemmän liikennekuolemia (ETSC 2015;
Löytty 2016). Naapurimaassamme Ruotsissa on ryhmän 1 ajokorttia haettaessa ja uusittaessa käytössä itseilmoitus, minkä lisäksi vaaditaan vain näkökyvyn testaus. Norjassa on sama käytäntö kuin Ruotsissa 75 ikävuoteen asti, minkä jälkeen hakijalta vasta vaaditaan lääkärintarkastus. (Löytty 2016.) Suomessa lääkärinlausunto vaaditaan kaikilta, ja tämän lisäksi ikääntyneiden lääkärintarkastusta on edellä mainituin tavoin laajennettu vuodesta 2013 alkaen. Toisaalta tuoreen hallituksen esityksen ( $\mathrm{HE}$ 146/2017) mukaan ajokorttilakiin ehdotetaan lieventäviä muutoksia ajoterveysvaatimusten täyttymisen seurannan osalta. Esityksessä ehdotetaan muun ohella, että muita kuin kuormaja linja-auton ajokortteja uudistettaessa lääkärinlausunto vaadittaisiin nykyisen 70 vuoden sijaan vasta seuraavan ajokortin uudistamisen yhteydessä noin 75 vuoden iässä.

\section{Muistisairaan ihmisen ajokyvyn arviointi}

Osa ajokortin haltijoista on muistisairauteen sairastuneita. Koska muistisairas ihminen ei sairauden lievässä vaiheessa automaattisesti menetä ajokorttiaan diagnoosin saatuaan, tulee ajokykyä arvioida ja seurata huolellisesti. Trafin (2016) lääkäreiden ajoterveyden arviointiohjeessa luetellaan kognitiivista suorituskykyä, älyllisen toimintakyvyn häiriötä ja muistisairauden asteen arviointia varten tarkoitettuja menetelmiä (mm. MMSE, CERAD, Moca), joilla lääkäri voi selvittää potilaan toimintakykyä (Trafi 2016). Partisen ja Sainion (2015) mukaan muistisairaan ihmisen ajoterveyden arvioinnin tukena lääkärin tulisi käyttää edellä mainittujen menetelmien lisäksi tarvittaessa neuropsykologista tutkimusta. Myös Viitanen ja Ojala (2015) korostavat erilaisten tutkimusmenetelmien käyttöä ajokyvyn arvioinnin apuna lääkärin vastaanotolla.

Ajoterveyden arviointiohjeiden (Trafi 2016) mukaan henkilön sairastaessa vähintään keskivaikeaa muistisairautta ryhmän 1 ajokorttia ei saa antaa tai sitä uudistaa hakijoil- 
le. Muistisairauden lievässä vaiheessa voi siis ryhmän 1 ajolupa vielä säilyä. Ryhmän 2 osalta ajoterveysvaatimukset eivät täyty, jos henkilöllä on muistisairaus sen asteesta riippumatta. Keskivaikea tai vaikea muistisairaus on siis aina este ajoluvalle. Muistisairauden vaikeusastetta määriteltäessä käytetään globaalia CDR-asteikkoa (Clinical Dementia Rating), jossa huomioidaan kuusi osa-alueetta: muisti, orientaatio, arvostelukyky, yhteisölliset toiminnot, koti ja harrastukset sekä itsestä huolehtiminen. Asteikolla arvo 0 edustaa normaalia, 0,5 lievästi poikkeavaa tai mahdollista muistisairautta, 1 lievää muistisairautta ja 2 tai suurempi vähintään keskivaikeaa sairauden vaihetta. (Rosenvall 2015.)

Partisen ja Sainion (2015) mukaan muistioireet voivat kuitenkin joskus korottaa arviota muistisairauden vaikeusasteesta ilman, että tutkittavalla on vielä ajokyvyn kannalta merkittäviä vaikeuksia. Tällaisissa tapauksissa saattaa ajoterveys olla riittävä, mutta myönteinen päätös edellyttää silloin aina ajokyvyn tai ajotaidon selvittämistä oikealla autolla. Ajokykyä suositellaan seurattavaksi lievän muistisairauden vaiheessa puolen vuoden välein (Trafi 2016).

Muistisairaan ihmisen ajokyvyn arvioinnissa ja seurannassa tulee kiinnittää huomiota kokonaisarvioon henkilön tilanteesta. Heikentyneestä ajokyvystä kielii vaikeiden ajotilanteiden välttäminen, vähäinen ajaminen, kolaroinnit, sakot, omaisten huoli, päihteiden käyttö, unihäiriöt sekä näkö- ja motoriset ongelmat (Löppönen \& Ojala 2017). Monisairastavuus ja lääkitys voivat myös heikentää muistisairaan ihmisen ajokykyä, jolloin kokonaisarvio sairastuneen tilanteesta on ratkaiseva (Hoffman Snyder 2005).

Löppösen ja Ojalan (2017) mukaan ajokyvyn arviointi on tärkeä osa hoitosuunnitelmaa, ja jo muistisairauden diagnosointivaiheessa se on syytä ottaa puheeksi. Lisäksi hyvin lievässä muistisairauden vaiheessa olevia tulisi vahvemmin tukea ajokyvyn turvalliseen ylläpitämiseen esimerkiksi ajoharjoittelulla, johon olisi nähdäksemme hyvä ohjata ja kannustaa muisti- ja geriatrisilla poliklinikoilla jo diagnoosin asettamisen vaiheessa. Tuossa vaiheessa ajokyky saattaa olla vielä hyvä. Samalla voisi aloittaa sairastuneen ja läheisten hienotunteisen ohjaamisen tunnistamaan niitä merkkejä, jotka edeltävät ajokortista luopumisen vaihetta, jotta ajamisen päättyminen sujuisi mahdollisimman mutkattomasti. Näin pyrittäisiin varmistamaan, ettei ajokyvyttömiä ihmisiä ole liikenteessä. Samalla sekä muistisairaiden ihmisten että muiden liikenteessä liikkuvien turvallisuus vahvistuisi. Ajokyvyn hiipuessa kannattaisi myös riittävän ajoissa aloittaa tutustuminen vaihtoehtoisiin ja turvallisiin liikkumisen keinoihin, joihin ohjaamisessa sosiaali- ja terveydenhuollon ammattihenkilöillä on merkittävä rooli.

Ajoterveyden valvonta kuuluu Suomessa poliisille. Ajokorttilain $21 \S: n$ mukaan lääkärin tulee ilmoittaa poliisille, jos hän toteaa ajokorttiluvan hakijan tai ajo-oikeuden haltijan terveydentilan muuten kuin tilapäisesti heikentyneen siten, ettei hän enää täytä ajokorttiluvan myöntämisen edellytyksenä olevia terveysvaatimuksia. Ennen ilmoituksen tekemistä potilaalle on kerrottava velvollisuudesta ilmoituksen tekemiseen ja terveydentilan vaikutuksesta ajokykyyn. Ryhmän 1 ajokorttiluokissa keskivaikea muistisairaus edellyttää ilmoitusta ajokorttiviranomaiselle. Ryhmän 2 kuljettaja kuuluu lääkärin ilmoitusvelvollisuuden piiriin heti muistisairauden varmistumisen jälkeen sairauden vaikeusasteesta riippumatta. Useissa muissakin Euroopan maissa on käytössä lääkärin ilmoitusvelvollisuus. Naapurimaistamme ilmoitusvelvollisuus on käytössä Latviassa, Liettuassa, Norjassa ja Ruotsissa. Tanskassa ilmoitusvelvollisuus on siinä tapauksessa, että sairaus tai tila aiheuttaa suoran riskin muille tienkäyttäjille eikä kuljettaja lopeta ajamistaan vapaaehtoisesti. (HE 146/2017). Hoffman Snyderin (2005) mukaan lääkärin ilmoitusvelvollisuus saattaa kuitenkin vaikuttaa lääkärin ja potilaan suhteeseen. Jos potilas pelkää ajokortin menettämistä, hän voi vältellä lääkäriin menoa ja jäädä ilman tarvitsemaansa hoitoa ja palveluita. 


\section{Ajo-oikeuden merkitys muistisairaalle ihmiselle}

Autoilu ja mahdollisuus itsenäiseen liikkumiseen ovat osa monen muistisairaan ihmisen toimintakykyä, identiteettiä, sosiaalisia suhteita ja yhteiskunnallista osallisuutta. Muistisairaat ihmiset ovat kuvanneet ajamisen olevan tärkeä osa myös heidän elämänlaatuaan (Adler 2010). Tutkimusten mukaan noin 40-50 prosenttia muistisairauden diagnoosin saaneista ihmisistä jatkaa ajamista (Carr 1997; Lloyd ym. 2001). Ajamisen kieltäminen voi rajoittaa perheenjäsenten ja ystävien kohtaamisia, mahdollisuuksia palveluihin, aiheuttaa masennusta ja on myös itsenäinen riskitekijä laitoshoitoon joutumiselle (Breen ym. 2007; Freeman, Gange, Munoz \& West 2006; Marottoli ym. 2000). Erityisesti maaseudulla, jossa ikääntyvien ihmisten osuus on korkea ja jossa julkinen liikenne ei usein ole kehittynyttä, mahdollisuus oman auton käyttöön on tärkeää (O'Hanlon ym. 2005). Autoilu vaikuttaa usein merkittävästi myös autoilevan muistisairaan ihmisen läheisen liikkumiseen, jos ajokortti on perheessä ainoastaan muistisairautta sairastavalla.

Ajo-oikeus voidaan nähdä myös hyvin tärkeäksi osaksi yksilön autonomiaa, jonka katsotaan olevan keskeinen muistisairaan ihmisen oikeusturvaa koskeva periaate (ks. esim. Harding 2012; Herring 2009; Mäki-Petäjä-Leinonen 2017a). Autonomia on moniulotteinen kokonaisuus. Se tarkoittaa jokaisen toimintakykyisen yksilön yhdenvertaista oikeutta päättää itseään koskevista asioista (Pietarinen 1993). Autonomian elementtejä ovat kyvykkyys, oikeus saada tietoa, mahdollisuus tehdä päätöksiä ja voimavaroja toteuttaa ne (Topo 2012). Autonomian periaatetta korostetaan muun ohella Euroopan neuvoston ikäihmisten ihmisoikeuksien edistämistä koskevassa suosituksessa (Recommendation CM/Rec(2014)2). Sen mukaan ikäihmisillä on oikeus elää elämäänsä itsenäisesti, itsemääräävästi ja autonomisesti.

Muistisairaan ihmisen kognitiivisten kykyjen heikentyminen johtaa kuitenkin väistämät- tä tilanteeseen, jossa hän ei enää kykene itsenäisesti tekemään päätöksiä asioistaan. Tällöin häntä saattaa olla tarpeen suojella hänen itsensä tai ulkopuolisten taholta tulevia oikeudenloukkauksia vastaan (Mäki-Petäjä-Leinonen 2013). Muistisairasta ihmistä suojataan niin ikään tilanteessa, jossa hänen henkilökohtaista vapauttaan joudutaan rajoittamaan esimerkiksi ajo-oikeus poistamalla. Tämän voidaan perustella olevan välttämätöntä paitsi sairastuneen itsensä myös muiden turvallisuuden takaamiseksi. Euroopan neuvoston suosituksessa ikäihmisten ihmisoikeuksien edistämisestä todetaan, että kaikkien mahdollisten autonomiaa koskevien rajoitustoimien tulee olla suhteellisia liittyen tapauksen olosuhteisiin, ja ne edellyttävät riittävän suojelun varmistamista hyväksikäyttöä ja syrjintää vastaan.

Muistisairaan ihmisen autonomiaa ja henkilökohtaista suojelua voidaan joutua punnitsemaan ajo-oikeusasiassa. Oikeutta ajo-oikeuden säilyttämiseen voidaan perustella sairastuneen oikeudella elää itsemääräävää elämää ja tosiasialla, että muistisairauden diagnoosi ei tarkoita automaattista ajokyvyn menettämistä (Alzheimer Europe 2012). Diagnoosin saatuaan monet muistisairaat myös tekevät autonomisen päätöksen autoilun lopettamisesta ja siirtymisestä julkisen liikenteen käyttäjiksi tai tekevät toimenpiteitä maksimoidakseen turvallisuuttaan. Muistisairauteen sairastunut saattaa esimerkiksi pysytellä hiljaisilla ja tutuilla reiteillä, välttää illalla tai sateessa ajamista taikka ajaa ainoastaan seurassa (Adler \& Kuskowski 2003).

On myös mahdollista, ettei muistisairas tiedosta alentunutta ajokykyään, jolloin ajokykyä ja mahdollista ajokortista luopumista on lähestyttävä päättäväisesti mutta erityisen hienotunteisesti. Usein muistisairaan omaiset ovat niitä, jotka ensin huolestuvat sairastuneen läheisensä ajamisesta. Perheenjäsenillä saattaa kuitenkin olla suuria vaikeuksia saada sairastunut lopettamaan ajaminen, ja he tarvitsevat siihen usein ulkopuolista apua (O'Neill 2010). Muistisairauteen sairastunut James McKillop 
(2012) on toiminut kokemusasiantuntijana muun ohella Alzheimer Europen työryhmässä, jossa on tarkasteltu muistisairaan ihmisen vapauden rajoituksia (Alzheimer Europe 2012). McKillop, joka itse on aikoinaan menettänyt ajokorttinsa vastoin tahtoaan, korostaa omaisten ja läheisten tärkeää roolia ja vastuuta puuttua ajokyvyttömän kuljettajan tilanteeseen. Hänen mukaansa se on kuitenkin lopulta ainoa oikea ratkaisu (vapaasti suomennettuna):

\begin{abstract}
”Älä odota, että kukaan luovuttaa autonsa avaimia ilman tappelua. Jos ne kuitenkin luovutetaan, ole tyytyväinen. Sairastunut saattaa olla tyrmistynyt ehdotuksesta autolla-ajosta luopumisesta. Ehdotus voi johtaa katkeraan syyttelyyn, joka saa sinut tuntemaan syyllisyyttä siitä, mitä olet tekemässä hänelle. Miten voit olla niin julma ja tunteeton? Mutta muista, sinulla on hoivavastuu hänestä, ihan kuten sinulla olisi vastuu kasvavasta lapsesta. On sydäntäsärkevää joutua tekemään oikea ratkaisu.”
\end{abstract}

On kuitenkin myös mahdollista, että osa muistisairauteen sairastuneista ihmisistä jatkaa ajamista siitä huolimatta, että he tiedostavat menettävänsä ajokykyään. Toisaalta muistisairas ihminen saattaa olla sairaudentunnoton, jolloin häneltä voi puuttua kyky huomata oman ajokykynsä heikentyminen. McKillop (2012) on kuvannut tilannettaan ennen muistisairauden diagnoosin saamista (vapaasti suomennettuna):

"Vaimoni Maureen kieltäytyi tulemasta kyytiini, jos ajoin... Hän huomautti, että jos menimme esimerkiksi moottoritielle, en pysynyt oikealla kaistalla, vaan ajelehdin kaistalta toiselle. En näyttänyt pystyvän ajamaan "suoraa linjaa”. Tämän minä tietysti sinnikkäästi kiistin. Minähän olin täydellinen kuljettaja. Jälkeenpäin katsottuna on selvää, että kärsin anosognosiasta eli sairaudentunnottomuudesta.”
Jos muistisairas ihminen ei suostu lopettamaan ajamista ja jättää mahdolliset läheisten pyynnöt huomiotta, läheiset yrittävät toisinaan löytää keinoja estääkseen sairastuneen ajamisen. He saattavat piilottaa auton avaimet, tekevät auton ajokelvottomaksi, antavat sairastuneen uskoa, että auto on epäkunnossa, parkkeeraavat auton näköpiirin ulkopuolelle tai jopa myyvät auton, mikäli heillä on siihen oikeus. Tämän kaltaiset keinot saatetaan kokea holhoaviksi, muistisairaan ihmisen autonomiaa loukkaaviksi, epärehellisiksi ja petollisiksi. Toisaalta niiden voidaan nähdä suojaavan yksilöä, jolla ei ole kykyä arvioida toimintansa vaarallisuutta itselle ja toisille (Alzheimer Europe 2012). Etiikan näkökulmasta yksilön itsensä ja muiden yksilöiden turvallisuuden suojeleminen (oikeus elämään) on niin vahva periaate, että sen perusteella tilanteeseen tulee puuttua, vaikka se herättäisikin sairastuneessa ärtymystä ja tunnetta, että on tullut huijatuksi. Sen sijaan toimimatta jättäminen tällaisessa tilanteessa on eettisesti arveluttavaa, sillä vahingon riski on selvästi kasvanut (vahingon välttämisen periaate). (Lääkintäetiikan periaatteista ks. esim. Beauchamp \& Childress 2001.)

\section{Vaihtoehtoisia ratkaisuja muistisairaan ihmisen liikkumisen turvaamiseen}

Tässä luvussa tarkastelemme erilaisia ratkaisuja muistisairaan ihmisen liikkumisen turvaamiseksi. Vaikka muistisairauden lievä vaihe ei ole vaatimus ajokortista luopumiselle kaikissa ajokorttiluokissa, joutuu muistisairas jossakin sairautensa vaiheessa väistämättä luopumaan ajamisesta. Liikkumisvapaus on taattu perusoikeutena perustuslain 9 §:ssä, ja se tulee taata myös muistisairaille ihmisille sairauden edetessä. Olemme valinneet tähän lukuun keskeisiä, mutta hyvin erilaisia näkökulmia, jotka edustavat yhdessä ja erikseen mahdollisia vaihtoehtoisia ratkaisuja muistisairaan ihmisen liikkumisen turvaamiseen. Tarkastelemme sähkömopoa esimerkkinä vaihtoehtoisesta liikkumisen 
välineestä, rajoitetun ajo-oikeuden säätämisen mahdollisuutta lainsäädännössämme sekä laissa säädettyjä liikkumista tukevia palveluja osana muistisairaan ihmisen liikkumista. Olemme rajanneet tarkastelun ulkopuolelle yhtä lailla tärkeät näkökulmat kuten julkisen liikenteen kehittämisen muistiystävällisemmäksi, erilaiset vapaaehtoisuuteen perustuvat tukihenkilö- ja avustajapalvelut kuten ystävä- tai muistikaveritoiminnan sekä kävellen liikkumisen tukemisen gps-teknologiaa hyödyntämällä. Nämä näkökulmat ansaitsevat oman tutkimuksensa.

\section{Sähkömopo vaihtoehtoisena liikkumisen välineenä}

Sähköisten ajoneuvojen, kuten sähkömopojen ja senioriskoottereiden suosio on lisääntynyt iäkkäiden henkilöiden käytössä. Jo vuonna 2012 YLE-uutiset kertoi maassamme olevan, maahantuojien ja jälleenmyyjien arvioiden mukaan, parituhatta ikäihmisille tarkoitettua sähkömopoa (YLE 19.4.2012). Myös lainsäätäjä on sähköajoneuvoja koskevan lainsäädäntöuudistuksen yhteydessä arvioinut sähkömopon ja senioriskootterin parantavan iäkkäiden henkilöiden mahdollisuuksia omaehtoiseen liikkumiseen (HE 24/2015).

Kolmipyöräiset sähkömopot voivat olla oivallisia välineitä monille sellaisille henkilöille, joiden liikkumiskyky on heikentynyt, sillä ne mahdollistavat itsenäisen liikkumisen. Tällaisia mopoja, joiden ajamiseen ei vaadita ajokorttia, markkinoidaan "kauppakassina, jolla saa ajaa ilman ajokorttia". Kalleimmat ja nopeimmat, $45 \mathrm{~km} / \mathrm{h}$ liikkuvat kopilliset sähkömopot tulee rekisteröidä. Kolmipyöräiset, 12 tai $25 \mathrm{~km} / \mathrm{h}$ kulkevat skootterit puolestaan eivät vaadi edes rekisterimerkintää.

Kun etsitään ratkaisuja ajokortin menettäneen muistisairaan ihmisen liikkumisen tukemiseen, saattaa sähkömopon ostaminen vaikuttaa hyvältä ratkaisulta. Tulee kuitenkin varoa, ettei liian innokkaasti pyritä tukemaan sairastuneen ihmisen autonomian toteutumista ja oikeutta ajamiseen liikenneturvallisuuden kus- tannuksella. Viime vuosina mediassa on nimittäin ollut esillä tapauksia, joissa ikääntynyt kuljettaja on aiheuttanut sähkömopolla vaarallisia tilanteita (ks. esim. YLE-uutiset 8.4.2015; KALEVA 14.8.2016). Tiedossa on myös keväällä 2017 sattunut tapaus, jossa henkilö jäi marketin parkkipaikalla sähkömopon alle. Iäkäs kuljettaja törmäsi henkilöön kolme kertaa, koska ei osannut sammuttaa ajoneuvoansa. Törmäyksen seurauksena syntyi lieviä vammoja. Toisessa tietoomme saamassamme tapauksessa muistisairauteen sairastuneen lapset olivat itsemääräämisoikeuteen vedoten hankkineet isälleen kopillisen sähkömopon. Tällä mopolla sairastunut sittemmin ajoi pysähtyneenä olleen henkilöauton perään.

Käsillämme ei ole laajempaa aineistoa siitä, missä määrin ajokorttinsa menettäneille muistisairaille ihmisille hankitaan edellä mainittuja sähkömopoja. Jos kysymyksessä on laajempikin ilmiö, tulisi erityistä huomioita kiinnittää sähkömopojen ja vastaavien ajoneuvojen myymiseen ja markkinointiin henkilöille, jotka ovat ajoterveyden ikätarkastuksessa menettäneet ajokorttinsa. On hyvin todennäköistä, että tällainen henkilö on menettänyt kykynsä myös sähkömopon hallintaan, eikä se täten ole suositeltava vaihtoehto muistisairaan liikkumisen turvaamiseen. Näissä tapauksissa sairastuneen itsensä ja muiden ihmisten turvallisuuden suojelemisen tulee olla määräävänä periaatteena.

Autoilijasta kevyen liikenteen käyttäjäksi siirtymisessä on myös huomioitava, että sähkömopo mahdollistaa varsin suuren ajonopeuden, mutta onnettomuuden sattuessa ajoneuvo itsessään tarjoaa kuljettajalleen vain vähän suojaa. Onnettomuuksien seuraukset ovat iäkkäille henkilöille usein vakavammat verrattuna nuorempiin kuljettajiin. Toki iäkäskin kuljettaja voi olla fyysisesti erittäin hyvässä kunnossa, mutta on todennäköisempää, että iäkkään kuljettajan keho on nuorempaa hauraampi ja täten alttiimpi vammoille onnettomuustilanteissa.

Ajokyvyn arviointia sekä seurantaa ja valvontaa sähkömopojen ja vastaavien ajoneuvojen osalta tulisikin kehittää. Esimerkiksi juuri säh- 
kömopon hankkimista harkitsevaa tulisi kannustaa ajoharjoitteluun, ja kenties esimerkiksi Liikenneturvan Ikäkuljettajan itsearviointi -testiä (2017) voisi pitää edellytyksenä ajoneuvon hankinnalle. Ohjausta ja neuvontaa turvallisen itsenäisen liikkumisen tukemiseksi tulisi järjestää muisti- ja geriatrisilla poliklinikoilla, joiden ammattihenkilöstöä tulisi myös riittävästi kouluttaa erilaisista vaihtoehdoista.

\section{Rajoitettu ajo-oikeus}

EU-direktiivi (2006/126/EY) antaa mahdollisuuden niin kutsuttuun rajoitettuun ajo-oikeuteen, joka on käytössä jo esimerkiksi Tanskassa, Itävallassa ja Ruotsissa. Rajatussa ajo-oikeudessa voidaan määrittää sallittu ajaminen esimerkiksi ajomatkan pituuden tai vuorokaudenajan mukaan tai vaikka alempien nopeusrajoitusten tieverkolle. Rajoitetun ajo-oikeuden käytöstä ikääntyneille kuljettajille on kuitenkin vain hyvin vähän tietoa. Löytyn (2016) mukaan Tanskassa lakia ei ole vielä sovellettu käytäntöön, ja Ruotsissa ja Itävallassa rajoitusmahdollisuus koskee kaikenikäisiä kuljettajia. Tilastotietoa näistä on saatavilla ainoastaan Ruotsista, jossa rajoitetun ajo-oikeuden saa vain noin 10-20 henkilöä vuodessa (Löytty 2016).

Rajoitettu ajo-oikeus voisi olla yksi mahdollisuus erityisesti maaseudulla asuville varhaisvaiheen muistisairautta sairastaville henkilöille. Parhaimmillaan rajoitettu ajo-oikeus voisi toimia ennaltaehkäisevästi ja kuntouttavasti muistisairaalle ihmisille (Partinen \& Sainio 2015). Koska Euroopassa rajoitetun ajo-oikeuden käytöstä ikääntyneillä kuljettajilla ei juurikaan ole tietoa (Löytty 2016), jää myös selvitettäväksi, miten mahdollisuus soveltuisi maahamme. Toisaalta yhdysvaltalaisten, kanadalaisten ja australialaisten tutkimusten mukaan (O’Byrne, Naughton \& O’Neill 2015) rajoitetulla ajo-oikeudella on selkeitä turvallisuushyötyjä. Rajoitetun ajo-oikeuden haltijoilla onnettomuusaste on alhaisempi verrokkikuljettajiin nähden. Muistisairauteen sairastunut
McKillop (2012) on kirjoittanut myös rajoitetun ajo-oikeuden puolesta (vapaasti suomennettuna):

"Olen sitä mieltä, että joissakin tilanteissa tulisi olla mahdollisuus rajoitetun ajooikeuden saamiseen. Rajoitettu ajo-oikeus voisi rajoittaa ajamisen esimerkiksi päiväsaikaan, tietyille ennalta määritellyille teille, asuinkaupungin sisälle, tietyn matkan säteelle omasta kodista tai tietyiksi tunneiksi päivästä. Jos henkilö asuu maaseudulla tai saarella, jossa on hiljainen liikenne tai olematon julkinen liikenne, ja sairastunut on läpäissyt ajotestin, rajoitettuun ajo-oikeuteen tulisi olla oikeus.”

Mahdollinen rajoitettu ajo-oikeus ei kuitenkaan ratkaisisi kaikkien muistisairaiden liikkumisen edellytyksiä, ja kenellekään muistisairaalle ihmiselle se ei olisi lopullinen vaihtoehto, sillä kuten edellä on todettu, muistisairaus johtaa väistämättä jossakin vaiheessa ajokyvyn menettämiseen. Huolimatta tutkimusnäytöstä rajoitetun ajo-oikeuden turvallisuushyödyistä (O’Byrne ym. 2015), tulisi aihetta edelleen tutkia nimenomaan muistisairaiden ihmisten ja muiden liikenteessä liikkuvien turvallisuuden näkökulmista Suomen olosuhteissa.

\section{Liikkumista tukevat palvelut}

Myös liikkumisen edellytyksiä turvaavat kunnan kuljetuspalvelut tukevat merkittävästi ajokortin menettänyttä muistisairasta ihmistä. Kunta voi myöntää kuljetuspalveluja joko sosiaalihuoltolain (1301/2014) tai vammaisuuden perusteella järjestettävistä palveluista ja tukitoimista annetun lain (380/1987, jäljempänä vammaispalvelulaki) nojalla.

Vammaispalvelulaki on toissijainen laki, joka tulee sovellettavaksi ainoastaan tapauksissa, joissa vammainen ei saa riittäviä palveluja muun lain, esimerkiksi sosiaalihuoltolain nojalla. Hiljattain uudistuneessa sosiaalihuoltolaissa säädetään liikkumisen tuen järjestämi- 
sestä (23 §) henkilöille, jotka eivät kykene itsenäisesti käyttämään julkisia liikennevälineitä alentuneen toimintakyvyn, sairauden, vamman tai muun vastaavanlaisen syyn vuoksi ja jotka tarvitsevat palvelua asioimisen tai muun jokapäiväiseen elämään kuuluvan tarpeen vuoksi. Hallituksen esityksen 164/2014 mukaan liikkumisen tukea tulisi myöntää etenkin sellaisille ikääntyneille, jotka tarvitsevat liikkumisen tukea ikääntymiseen liittyvän toimintakyvyn heikentymisen johdosta. Vaikka lain esitöissä mainitulla toimintakyvyn heikentymisellä oletettavasti viitataan myös muistisairaisiin ihmisiin, tämä perustelu ei ole onnistunut. Muistisairaudet kun eivät ole osa (normaalia) ikääntymisestä johtuvaa toimintakyvyn heikentymistä, vaan ne ovat neurologisia sairauksia.

Sosiaalihuoltolaissa ei myöskään ole liikkumisen tuen määrästä tarkempia säännöksiä. Usein muistisairaat eivät saa sosiaalihuoltolain perusteella riittävästi matkoja tarpeisiinsa nähden, mutta eivät joko tiedä olevansa oikeutettuja hakemaan lisämatkoja vammaispalvelulain nojalla tai hakevat, mutta eivät saa (Nikumaa, Ryynänen \& Koponen 2015). Vammaispalvelulain nojalla myönnettäviin kuljetuspalveluihin hakijan tulee puolestaan täyttää vammaispalveluasetuksen 5 §:ssä määritellyt vaikeavammaisuuden kriteerit (759/1987). Kyseistä määritelmää vaikeavammaisuudesta on kuitenkin perinteisesti tulkittu pitkälti sairauden tai vamman aiheuttaman fyysisen kävelykyvyn perusteella, mikä ei aina ole suosiollinen muistisairaalle. Muistisairas ihminen voi kyetä hyvin kävelemään esimerkiksi matkan lähimmälle joukkoliikennepysäkille. Arjessa sairaus tulee kuitenkin jossain vaiheessa esteeksi, eikä sairastunut enää kenties tunnista oikeaa pysäkkiä, suoriudu lipun ostamisesta tai muista, missä hänen piti jäädä pois.

Käytännössä muistisairaiden ihmisten yhdenvertainen oikeus vammaispalveluihin ei toteudu kaikilla alueilla, sillä muistisairauden aiheuttamaa kognitiivisen toimintakyvyn heikentymää ei aina pidetä riittävänä perusteena tukimuotojen myöntämiselle (Hoppania,
Mäki-Petäjä-Leinonen \& Nikumaa 2017; Nikumaa ym. 2015). Tästä voidaan esimerkkeinä mainita muun ohella korkeimman hallinto-oikeuden ratkaisut vuodelta 2005 (KHO 2005:36; KHO 2005:1400), joissa Alzheimerin tautia sairastanutta ei katsottu vaikeavammaiseksi suhteessa kuljetuspalveluihin. Näitä ratkaisuja on pidetty usean kunnan sosiaalityössä ohjenuorana (Nikumaa ym. 2015).

Tarkasteltaessa lähemmin oikeustapauksia koskien muistisairaiden ihmisten oikeutta vammaispalvelulain mukaisiin kuljetuspalveluihin, voidaan havaita, että oikeuskäytäntö asiassa ei ole vakiintunutta, ja ratkaisut ovat osaltaan jopa ristiriidassa keskenään. On olemassa nimittäin myös ratkaisuja, joissa sekä iäkäs henkilö (KHO 1998:134; KHO 2012:59; KHO 2012:60) että muistisairas ihminen (KHO 1999:442; KHO 2006:572) on katsottu vammaispalvelulain mukaiseksi vaikeavammaiseksi. Jälkimmäisissä ratkaisuissa muiden sairauksien tosin katsottiin muistisairauden ohella vaikuttaneen yksilön toimintakykyyn: ensimmäisessä tapauksessa toimintakykyä heikensi muistisairauden ohella sairastuneen huimaus, toisessa tapauksessa lonkan murtuma. Myös tuoreimmat korkeimman hallinto-oikeuden ratkaisut ovat keskenään erisuuntaisia. Ratkaisussa KHO 2014:3766 Alzheimerin tautia sairastava henkilö katsottiin muistisairauden aiheuttamien orientaatio-, hahmottamis- ja muistivaikeuksien vuoksi vaikeavammaiseksi ja oikeutetuksi kuljetuspalveluihin, kun taas hyvin tuoreessa ratkaisussa KHO 2017:96 Alzheimerin tautia sairastavaa henkilöä ei katsottu edenneen muistisairauden oireiden vuoksi vaikeavammaiseksi eikä täten oikeutetuksi kuljetuspalveluihin.

Tällä hetkellä vammaispalvelulaki on maassamme uudistuksen alla. Tavoitteena on sovittaa yhteen nykyinen vammaispalvelulaki ja kehitysvammaisten erityishuollosta annettu laki (519/1977) uudeksi vammaispalveluja koskevaksi erityislaiksi eri vammaryhmien yhdenvertaisten palvelujen turvaamiseksi. Luonnos hallituksen esitykseksi eduskunnalle laiksi 
vammaisuuden perusteella järjestettävistä erityispalveluista julkaistiin 17.5.2017.

Muistisairaiden ihmisten osalta tilanne ei kuitenkaan näytä lupaavalta. Valmisteilla olevaan uuteen vammaispalvelulakiin nimittäin ehdotetaan rajausta, jonka mukaan lakia ei sovellettaisi henkilöön, jonka avun tai tuen tarve johtuu pääasiassa korkean iän myötä alkaneista, lisääntyneistä tai pahentuneista sairauksista tai vammoista taikka korkeaan ikään liittyvästä rappeutumisesta (HE luonnos 17.5.2017). Pykäläperusteluissa (s. 9) todetaan, että tällöin palvelut järjestettäisiin ikääntyneen väestön toimintakyvyn tukemisesta sekä iäkkäiden sosiaali- ja terveyspalvelujen järjestämisestä annetun lain (980/2012, jäljempänä vanhuspalvelulaki) ja sosiaalihuoltolain mukaisesti. Valitettavasti vanhuspalvelu- tai sosiaalihuoltolaki ei kuitenkaan takaa muistisairaille subjektiivista oikeutta sellaisiin erityispalveluihin, kuten henkilökohtaiseen apuun tai liikkumista tukeviin palveluihin (ent. kuljetuspalvelut), joihin muilla sairaus- ja vammaryhmillä on yhdenvertainen oikeus.

Edelleen rajauksen perusteluissa kuitenkin todetaan, ettei kategorista ikärajaa asetettaisi, vaikka samalla viitataan vanhuspalvelulain hallituksen esityksen (HE 160/2012) kohtaan, jossa todetaan että "yleensä ihmisen toimintakyky heikkenee ja palvelujen tarve kasvaa merkittävästi noin 80-85 ikävuoden vaiheilla”. Perusteluista herää kysymys, asetetaanko rajaus sittenkin ikävuosiin 80-85.

Rajauksen perustelut asettavat myös eri muistisairautta sairastavat keskenään eriarvoiseen asemaan. Esityksessä nimittäin ohjataan arvioimaan palveluprosessissa sitä, mikä on normaaliin ikääntymiseen liittyvää toimintakyvyn heikkenemistä käyttämällä vertailuryhmänä henkilön ikäryhmän tavanomaista toimintakykyä. Esityksen mukaan lähtökohtana tulisi olla sen arvioiminen, onko sairaus ja sen esiintyvyys yleinen tietyssä ikäryhmässä ja siten katsottavissa yleisesti korkeasta iästä johtuvaksi. Tästä herää huoli, miten rajausta sovellettaisiin eri muistisairauksiin. Jos Alzheimerin tau- ti on yleisin muistisairauksista, mutta Lewyn kappale -tauti selkeästi harvinaisempi, olisiko Lewyn kappale -tautia sairastavalla mahdollisesti oikeus lain tarkoittamiin palveluihin, mutta Alzheimerin tautia sairastavalla ei. Vai olisiko vastaava oikeus vain esimerkiksi otsaohimolohkorappeumasta johtuvaa muistisairautta sairastavilla, sillä kysymyksessä olevan sairauden esiintyvyys on vain noin viisi prosenttia kaikista muistisairauteen sairastuneista (Käypä hoito -suositus 2017).

Toisaalta perusteluissa mainitaan esimerkkinä tilanne, jossa 50-vuotiaan toimintakyky heikkenee sellaisesta syystä, joka on tyypillinen yli 80-vuotiailla. Hallituksen esitysluonnoksen mukaan henkilöä ei pelkästään tästä syystä voitaisi sulkea pois ehdotetun lain piiristä. Toisin sanoen ehdotuksen mukaan nuorena Alzheimerin tautiin sairastuneella voisi olla yhdenvertainen oikeus vammaispalveluihin, mutta 80-vuotias suljettaisiin lain soveltamisen ulkopuolelle.

Huolimatta siitä, että rajauksen perusteluissa todetaan, ettei kategorista ikärajaa asetettaisi, voidaan ehdotettu rajaus nähdä eri sairaus- ja vammaryhmien yhdenvertaisuuden näkökulmasta jopa syrjintää tukevana. Rajausta voidaan pitää paitsi perustuslain (731/1999) yhdenvertaisuussäännöksen (6.2 §) ja yhdenvertaisuuslain (1325/2014) syrjinnän kieltoa koskevan 8 §:n myös YK:n vammaissopimuksen tasa-arvoa ja yhdenvertaisuutta koskevan 5. artiklan vastaisena. Kansainvälisesti yleinen käsitys nimittäin on, että muistisairaat ihmiset ovat vammaisia ja että YK:n vammaisten henkilöiden oikeuksia koskeva yleissopimus koskee myös heitä (ks. esim. Dementia Alliance International). Sopimuksen 9. artiklan mukaan sopimuspuolet toteuttavat asianmukaiset toimet varmistaakseen vammaisille henkilöille muiden kanssa yhdenvertaisen pääsyn fyysiseen ympäristöön ja kuljetukseen, jotta vammaiset henkilöt voisivat elää itsenäisesti ja osallistua täysimääräisesti kaikilla elämänalueilla.

Suomi ratifioi YK:n vammaissopimuksen vuonna 2016. Täyttääkseen sopimuksen vel- 
voitteet tulisi pitää huoli siitä, että uudistuva suomalainen vammaislainsäädäntö ei sulje pois muistisairaita eikä ikääntyviä vammaisia (Mäki-Petäjä-Leinonen 2017b). Nyt ehdotettu rajaus jättäisi käytännössä muistisairaat ihmiset vammaispalvelujen ulkopuolelle, vaikka se olisi yhdenvertaisuusperiaatteen vastaista ja lisäisi sairaiden ja vammaisten eriarvoisuutta (MäkiPetäjä-Leinonen \& Nikumaa 2015).

\section{Yhteenveto}

Ikääntyvien kuljettajien määrän lisääntyessä myös muistisairaiden ihmisten osuus ajokortin haltijoissa kasvaa. Vaikka etenevä muistisairaus johtaa edetessään vääjäämättä ajokortista luopumiseen, ei pelkkä diagnoosi sairauden lievässä vaiheessa tarkoita ajoluvan menettämistä ajokorttilain mukaisessa ryhmässä 1 (AjokorttiL 4 §). Onnettomuusriski kuitenkin kasvaa sairauden edetessä (Breen ym. 2007). Myös yksilölliset erot voivat olla merkittäviä, ja muistisairaan ihmisen ajokyvyn arvioinnissa ja seurannassa tuleekin kiinnittää huomioita kokonaisarvioon henkilön tilanteesta.

Suomalainen ajokorttilainsäädäntö sekä ajoterveyteen liittyvät ohjeet ovat hiljattain muuttuneet. Vaikka tutkimustieto (Siren \& Meng 2012) ei puolla ikään perustuvien seulontojen turvallisuus- tai kustannushyötyjä, on Suomessa ikääntyneiden kuljettajien tullut vuodesta 2013 alkaen käydä niin kutsutussa laajennetussa lääkärintarkastuksessa ajokorttia varten. Monissa maissa tarkastuksista on jo luovuttu ja käytössä on itseilmoitus.

Ajaminen on usein merkittävä osa muistisairaiden elämänlaatua, toimintakykyä, identiteettiä, sosiaalisia suhteita ja yhteiskunnallista osallisuutta. Ajo-oikeus voidaan nähdä myös tärkeäksi osaksi yksilön autonomiaa. Kuitenkin etiikan näkökulmasta yksilön itsensä ja muiden yksilöiden turvallisuuden suojeleminen (oikeus elämään) on niin vahva periaate, että sen perusteella tilanteeseen tulee puuttua, jos havaitaan, että sairastunut ei kykene enää kuljettamaan ajoneuvoa turvallisesti.

Koska muistisairaudet edetessään johtavat ajo-oikeuden menettämiseen, tulisi riittävän ajoissa aloittaa tutustuminen vaihtoehtoisiin ja turvallisiin liikkumisen keinoihin. Ikääntyvien ja muistisairaiden ihmisten lukumäärän kasvaessa tulisi myös erilaisia vaihtoehtoja liikkumisen turvaamiseen edelleen kehittää (Taylor \& Tripodes 2001). Esimerkiksi rajoitetun ajo-oikeuden mahdollisuutta voisi edelleen maassamme selvittää erityisesti syrjäseuduilla asuvien varhaisvaiheen muistisairaiden ja muiden liikenteessä liikkuvien näkökulmista. Ajokortista luopumisen jälkeen muistisairaille ihmisille tulisi taata muiden sairaus- ja vammaryhmien tavoin yhdenvertainen oikeus vammaispalvelulain nojalla myönnettäviin kuljetuspalveluihin. Meneillään olevassa vammaispalvelulain uudistustyössä tulisi huomioida se tosiasia, että myös muistisairas ihminen on vammainen ja hänelle tulee taata oikeus osallistua yhteiskuntaan sen tasavertaisena jäsenenä. Yhdenvertaisuuden ja syrjimättömyyden näkökulmasta tulisi huolehtia siitä, että henkilöt, jotka ovat menettäneet ajokorttinsa muistisairauden vuoksi, eivät eristy yhteiskunnasta. Huomiota tulee kiinnittää erityisesti sellaisten muistisairaiden ihmisten tilanteeseen, jotka ovat olleet riippuvaisia ajo-oikeudestaan (Alzheimer Europe 2012).

\section{Kiitokset}

Haluamme kiittää anonyymejä arvioitsijoita arvokkaista palautteista, sekä käsikirjoituksen eri vaiheissa lukeneita sosiaaligerontologian emeritusprofessoria Antti Karistoa (Helsingin yliopisto), siviilioikeuden emeritusprofessoria Urpo Kangasta (Helsingin yliopisto) sekä perheja jäämistöoikeuden yliopistonlehtoria Tapani Lohea (Helsingin yliopisto) heidän kallisarvoisista kommenteistaan, jotka merkittävästi veivät käsikirjoitusta eteenpäin. Lisäksi kiitämme tutkijatohtori Mika Sutelaa (Itä-Suomen yli- 
opisto) ideasta tämän artikkelin kirjoittamiseen. Kiitämme myös tutkimustyötämme tukeneita Suomen Aivosäätiötä, Helena Lavikaisen säätiötä sekä Suomen Kulttuurirahastoa.

\section{Yhteydenotto:}

Henna Nikumaa, sosionomi (YAMK), tohtorikoulutettava

Helsingin yliopisto

Sähköposti: henna.nikumaa@helsinki.fi

\section{Kirjallisuus}

Ajokorttilaki 29.4.2011/386.

Aarsland, D., Zacca, J. \& Brayne C. (2005). A systematic review of prevalence studies of dementia in Parkinson's disease. Movement Disorders, 20, 1255-63.

Adler, G. \& Kuskowski, M. (2003). Driving cessation in older men with dementia. Alzheimer Disease and Associated Disorders, 17(2), 68-71.

Adler, G. (2010). Driving decision-making in older adults with dementia. Dementia, 9(1), 45-60.

Alhainen, K. (2001). Dementoivien sairauksien tunnistaminen ja diagnostiikka. Teoksessa Heimonen, S. \& Voutilainen P. (toim.), Dementoituran hoitopolku (s. 21-37). Helsinki: Tammi.

Alzheimer Europe (2012). The ethical issues linked to restrictions of freedom of people with dementia. Haettu 18.3.2017 osoitteesta: http://www.alzheimer-europe.org/Ethics/Ethical-issues-in-practice/2012-The-ethical-issues-linked-to-restrictions-of-freedom-of-people-with-dementia/ The-restriction-of-the-freedom-to-play-an-active-role-in-society

Beauchamp, T. \& Childress, J. (2001). Principles of Biomedical Ethics. New York: Oxford University Press.

Breen, D.A., Breen, D.P., Moore,J.W., Breen, P.A. \& O'Neill, D. (2007). Driving and dementia. BMJ, 334(7608), 1365-1369.

Brown, LB., Ott, BR., Papandonatos, GD., Sui, Y., Ready, RE. \& Morris, JC. (2005). Prediction of on-road driving performance in patients with early Alzheimer's disease. Journal of the American Geriatrics Society, 53, 94-98.

Carr, D.B. (1997). Motor vehicle crashes and drivers with DAT. Alzheimer's Disease and Associated Disorders, 11, 38-41.

Dellinger, A.M., Kresnow, M.J., White, D.D. \& Sehgal, M. (2004). Risk to self versus risk to others: how do older drivers compare to others on the road? American Journal of Preventive Medicine, 26(3), 217-221.
Dementia Alliance International. (2016). The $\mathrm{Hu}-$ man Rights of People Living with Dementia: from Rhetoric to Reality. A Dementia Alliance International publication. Haettu 27.3.2017 osoitteesta: https://www.dementiaallianceinternational.org/wp-content/uploads/2016/04/TheHuman-Rights-of-People-Living-with-Dementia-from-Rhetoric-to-Reality.pdf

Drachman, D.A. \& Swearer, J.M. (1993). Driving and alzheimer's disease: the risk of crashes. $\mathrm{Neu}$ rology, 43(12), 2448-2456.

Dubinsky, RM., Stein, AC. \& Lyons, K. (2000). Practice parameter: risk of driving and Alzheimer's disease (an evidence-based review). Neurology, 54, 2205-2211.

Dubois, B. \& Albert, M. (2004). Amnestic MCI or prodromal Alzheimer's disease? Lancet Neurology, 3(4), 246-248.

Emre, M., Aarsland, D. \& Brown, R. (2007). Clinical diagnostic criteria for dementia associated with Parkinson's disease. Movement Disorders Journal, 22, 1689-707.

Erkinjuntti, T., Remes, A., Rinne, J. \& Soininen, H. (2015). Muistisairaudet: käsitteitä ja termejä. Teoksessa Erkinjutti, T., Remes, A., Rinne, J. \& Soininen, H. (toim.), Muistisairaudet (s. 18-22). Helsinki: Duodecim.

ETSC. (2015). Ranking EU progress on road safety. 9th Road Safety Performance Index Report. June 2015. Haettu 24.3.2017 osoitteesta: http://etsc. $\mathrm{eu} / \mathrm{wp}$-content/uploads/ETSC-9th-PIN-Report_Final.pdf

EU kolmas ajokorttidirektiivi 2006/126/EY.

Evans, L. (2000). Risks older drivers face themselves and threats they pose to other road users. International Journal of Epidemiology, 29(2), 315-322.

Ferri, C.P., Prince, M., Brayne, C., Brodaty, H., Fratiglioni, L., Ganguli, M., Hall, K., Hasegawa, K., Hendrie, H., Huang, Y., Jorm, A., Mathers, C., Menezes, P.R., Rimmer, E. \& Scazufa, M. (2005). 
Global prevalence of dementia: a Delphi consensus study. Lancet, 366, 2112-2117.

Fook, J. (2004). Transformative Possibilities of Critical Reflection. Teoksessa Davies, L. \& Leonard, P. (toim.), Scepticism/Emancipation: Social Work in a Corporate Era (s. 16-30). Ashgate: Aldershot.

Freeman, E. E., Gange, S. J., Muñoz, B. \& West, S. K. (2006). Driving status and risk of entry into long-term care in older adults. American Journal Public Health, 96(7), 1254-1259.

Gardner, RC., Valcour, V. \& Yaffe, K. (2013). Dementia in the oldest old: a multi-factorial and growing public health issue. Alzheimers Researh ET Therapy, 5, 27.

Grace, J., Amick, MM., D’Abreu, A., Festa, EK., Heindel, WC. \& Ott, BR. (2005). Neuropsychological deficits associated with driving performance in Parkinson's and Alzheimer's disease. Journal of the International Neuropsychological Society, 11, 766-775.

Hakamies-Blomqvist, L., Johansson, K. \& Lundberg, C. (1996). Medical screening of older drivers as a traffic safety measure. A comparative Finnish - Swedish evaluation study. Journal of the American Geriatrics Society, 44, 650-653.

Harding, R. (2012). Legal constructions of dementia: discourses of autonomy at the margins of capacity. Journal of Social Welfare E Family Law, 34(4), 425-442.

Herring, J. (2009). Loosing it? Loosing what? The law and dementia, Child and Family Law Quarterly, 21(1), 3-29.

HE 212/2010. Hallituksen esitys Eduskunnalle ajokorttilaiksi ja eräiksi siihen liittyviksi laeiksi.

HE 160/2012. Hallituksen esitys Eduskunnalle Hallituksen esitys eduskunnalle laiksi ikääntyneen väestön toimintakyvyn tukemista sekä iäkkäiden sosiaali- ja terveyspalveluista sekä laiksi terveydenhuoltolain 20 §:n kumoamisesta.

HE 164/2014. Hallituksen esitys Eduskunnalle sosiaalihuoltolaiksi ja eräiksi siihen liittyviksi laeiksi.

HE 24/2015. Hallituksen esitys eduskunnalle laeiksi ajoneuvolain, tieliikennelain ja rikoslain 23 luvun 9 ja 12 §:n muuttamisesta.

HE 146/2017. Hallituksen esitys eduskunnalle laiksi ajokorttilain muuttamisesta.

HE luonnos 17.5.2017. Hallituksen esityksen luonnos eduskunnalle laiksi vammaisuuden perusteella järjestettävistä erityispalveluista.
Hoffman Snyder, C. (2005). Dementia and driving: autonomy versus safety. Journal of the American Accociation of Nurse Practitioners, 17(10), 393-402.

Hoppania, H-K, Mäki-Petäjä-Leinonen, A., \& Nikumaa, H. (2017). (Un)equal treatment? People with Dementia between Elder Care and Disability Services in Finland. European Journal of Social Security, 19(3), 225-241.

Iverson, D. J., Gronseth, G.S., Reger, M.A., Glassen, M., Dubinsky, R.M. \& Rizzo, M. (2010). Practice parameter update: Evaluation and management of driving risk in dementia: report of the Quality Standards Subcommittee of the American Academy of Neurology. Neurology, 74(16), 1316-1324.

Kalenoja, H., Tiikkaja, H. \& Kallberg, H. (2008). Henkilöauton ajo-oikeuden baltijat. Ennuste henkilöauton ajo-oikeuden haltijoiden jakaumasta vuosille 2010-2040. Ajoneuvohallintokeskus, Tutkimuksia ja selvityksiä, Nro 13/2008. Helsinki.

Kalenoja, H. \& Tuominen, J. (2016). Ikäkuljettajien kokemukset liikenteestä. Vuosien 2014-2015 aineisto. Trafin tutkimuksia 8/2016. Helsinki: Liikenteen turvallisuusvirasto Trafi.

Kuikka, P., Summala, H., Kalakoski, V. \& Sallinen, M. (2012). Ikääntyminen ja ajaminen. Ajokyvyn kognitiivisten edellytysten arviointi muistisairauksien ja aivohalvausten jälkitilojen yhteydessä. Liikenneturvallisuuden pitkän aikavälin tutkimusja kehittämisohjelma LINTU-julkaisuja 1/2012. Helsinki: Liikenne- ja viestintäministeriö.

Käypä hoito -suositus. (2017). Muistisairaudet. Duodecim. Haettu 11.3.2017 osoitteesta:

http://www.kaypahoito.fi/web/kh/suositukset/ suositus?id=hoi50044\#NaN

Lafont, S., Gabaude, C., Paire-Ficout, L. \& Fabrigoule, C. (2010). Des conducteurs âgés moins dangereux pour les autres: étude des accidents corporels en France entre 1996 et 2005. Le Travail Humain 73(1), 75-92.

Laki ikääntyneen väestön toimintakyvyn tukemisesta sekä iäkkäiden sosiaali- ja terveyspalvelujen järjestämisestä 28.12.2012/980.

Laki kehitysvammaisten erityishuollosta 23.6.1977/ 519.

Laki vammaisuuden perusteella järjestettävistä palveluista ja tukitoimista 3.4.1987/380.

Liikenneturvan Ikäkuljettajan itsearviointi -testi. Haettu 29.3.2017 osoitteesta: http://extrat.liikenneturva.fi/kuljettajanitsearviointi/new/ 
Lloyd, S., Cormack, C.N., Blais, K., Messeri, G., McCallum, M.A., Spicer, K. \& Morgan, S. (2001). Driving and dementia: a review of the literature. Canadian Journal of Occupational Therapy, 68(3), 149-156.

Löppönen, M. \& Ojala, M. (2017). Muistisairaan ajokyvyn arviointi. Käypä hoito -suositus. Haettu 11.3.2017 osoitteesta: http://www.kaypahoito.fi/ web/kh/suositukset/suositus?id=nix02421\#NaN

Löytty, M. (2016). Ajo-oikeuden hakijoiden, haltijoiden ja unsijoiden terveysvaatimusten täyttymisen varmistamisen käytännöt Euroopassa. Trafin julkaisuja 15/2015. Helsinki: Liikenteen turvallisuusvirasto Trafi. Haettu 12.3.2017 osoitteesta: https://www.trafi.fi/filebank/a/1452498305/ 82fa726bca6f0b0ddea6a908cb7e36b2/19461Trafin_julkaisu_15-2015.pdf

Marottoli, R. A., de Leon, C. F., Glass, T. S., Williams, C. S., Cooney, L. M. \& Berkman, L. F. (2000). Consequences of driving cessation: decreased out-of-home activitiy levels. The Journals of Gerontology, Series B, Psychological Sciences and Social Sciences, 55(6), 334-340.

Martensen, H. \& Diependale, K. (2014). Comparison of European Countries with and without age based screening of older drivers. Haettu 20.3.2017 osoitteesta: http://www.bast.de/DE/ Verkehrssicherheit/Publikationen/Veranstaltungen/U-Ageing-2014/Downloads-Presentations/ Martensen-Vortrag.pdf?__blob=publicationFile\&v=

McKillop, J. (2012). Living with Dementia. Personal experiences of living with dementia. James McKillop describes his experience of the impact living with dementia has had in relation to driving in the UK. Last Updated: Thursday 15 March 2012. Haettu 30.3.2017 osoitteesta: http://www.alzheimer-europe.org/Living-with-dementia/Personal-experiences-of-living-with-dementia/James-McKillop-Scotland

Meuleners, L., Ng, J., Chow, K. \& Stevenson, M. (2016). Motor Vehicle Crashes and Dementia: A Population-Based Study. Journal of the American Geriatrics Society, (64), 1039-1045.

Mezirow, J. (1998). On Critical Reflection. Adult Education Quarterly, 48(3), 185-198.

Mikkonen, V. (2010). Seniorikuljettajien seurantaindeksi. Liikenteen turvallisuusvirasto Trafi. Trafin julkaisuja 5/2010. Helsinki: Liikenteen turvallisuusvirasto Trafi.
Mikkonen, V. (2014). Ajokortin uusintaan liittyvien ikäkausitarkastusten vaikutus liikennemenestykseen. Trafin tutkimuksia 02/2014. Helsinki: Liikenteen turvallisuusvirasto Trafi.

Mitchell, C.G.B. (2008). The licensing of older drivers in Europe - a case study. Traffic Injury Prevention, 9, 360-366.

Mäki-Petäjä-Leinonen, A. (2013). Ikääntymisen ennakointi - Vanhuuteen varautumisen keinot. Helsinki: Talentum.

Mäki-Petäjä-Leinonen, A. (2017a). Protecting a Person with Dementia through Restrictions of Freedom? Notions of Autonomy in the Theory and Practice of Elder Care. Teoksessa Griffiths, A., Mustasaari, S, \& Mäki-Petäjä-Leinonen, A. (toim.), Subjectivity, Citizenship and Belonging in Law: Identities and Intersections (s. 146-170). Abingdon: Routledge.

Mäki-Petäjä-Leinonen, A. (2017b). Mitä on vanhuusoikeus. Teoksessa Mäki-Petäjä-Leinonen, A. \& Karvonen-Kälkäjä, A. (toim.), Vanhuusoikeuden perusteet. Helsinki: AlmaTalent.

Mäki-Petäjä-Leinonen, A. \& Nikumaa, H. (2015). Lain tulisi kohdella muistisairasta vammaisena. Helsingin Sanomat, Vieraskynä 10.10.2015.

Nikumaa, H., Ryynänen, V. \& Koponen, E. (2015). Muistisairaiden ihmisten yhdenvertainen oikeus vammaispalveluihin. Osa 1 Kuljetuspalvelut. Memo, 1, 17-19.

O’Byrne, C., Naughton, A. \& O'Neill, D. (2015). Is driver licensing restriction for age -related medical conditions an effective mechanism to improve driver safety without unduly impairing mobility? European Geriatric Medicine, 6, 541-544.

O’Hanlon, A., McGee, H., Barker, A., Garavan, R., Hickey, A., Conroy, R. \& O’Neill D. (2005). Health and Social Services for Older People II (HeSSOP II): Changing Profiles from 2000 to 2004. Dublin: National Council on Ageing and Older People.

O'Neill, D. (2010). Deciding on driving cessation and transport planning in older drivers with dementia. European Geriatric Medicine, 1, 22-25.

OTI-vuosiraportti 2015. (2015). Liikenneonnettomunksien tutkijalautakuntien tutkimat kuolemaan johtaneet tieliikenneonnettomuudet. Helsinki: Onnettomuustietoinstituutti, Liikennevakuutuskeskus.

Ott, BR., Heindel, WC., Papandonatos, GD., Festa, EK., Davis, JD., Daiello, LA. \& Morris, JC. 
(2008). A longitudinal study of drivers with $\mathrm{Alz}^{-}$ heimer's disease. Neurology, 70, 1171-1178.

Partinen, M. \& Sainio, M. (2015). Ajokyky. Teoksessa Erkinjutti, T., Remes, A., Rinne, J. \& Soininen, H. (toim.), Muistisairaudet (s. 569-578). Helsinki: Duodecim.

Pietarinen, J. (1993). Itsemääräämisen periaate. Teoksessa Launis, V. \& Räikkä,J. (toim.), Itsemääräämisoikeus (s. 97-132). Turku: Turun yliopisto.

Recommendation CM/Rec(2014)2 of the Committee of Ministers to member States on the promotion of human rights of older persons. Haettu 15.6.2017 osoitteesta: http://www.refworld.org/ docid/53fdc73e $4 . h t m l$

Rosenvall, A. (2015). Toimintakyvyn ja muistisairauden vaikeusasteen arvioiminen. Teoksessa Erkinjutti, T., Remes, A., Rinne, J. \& Soininen, H. (toim.), Muistisairaudet (s. 386-391). Helsinki: Duodecim.

Siltala, R. (2003). Oikeustieteen tieteenteoria. Helsinki: Suomalainen lakimiesyhdistys.

Siren, A. \& Haustein, S. (2015). Driving licences and medical screening in old age: Review of literature and European licensing policies. Journal of Transport \& Health, 2, 68-78.

Siren, A. \& Meng, A. (2012). Cognitive screening of older drivers does not produce safety benefits. Accidident, Analysis and Prevention, 45, 634-638.

Sosiaalihuoltolaki 30.12.2014/1301.
Suomen perustuslaki 11.6.1999/731.

Taylor, B. D. \& Tripodes, S. (2001). The effects of driving cessation on the elderly with dementia and their caregivers. Accident Analysis and Prevention, 33(4), 519-528.

Topo, P. (2012). Autonomia on arkinen asia. Memo 2012:3. Haettu 15.6.2017 osoitteesta: http://www. muistiasiantuntijat.fi/memo.php?udpview=rea$\mathrm{d} \& \mathrm{src}=\mathrm{db} 25114 \& \mathrm{sid}=78 \&$ issue $=2012-03$

Trafi. (2016). Ajoterveyden arviointiohjeet lääkäreille 2016. Liikenteen turvallisuusvirasto 3.2.2016. Haettu 12.3.2017 osoitteesta: https://lomake. fi/c/ec/lomakepalvelu/download?s=0SMbosrli6w4Sqy\&id=15013\%2F814AF19AD64E892F8D9F8FE403BC5068\&type=statics

Viitanen, M. \& Ojala, M. (2015). Muistisairaudet ja ajoterveys. Suomalainen Lääkärilehti, 40, 26092613.

Viramo, P. \& Sulkava, R. (2015). Muistisairauksien epidemiologia. Teoksessa Erkinjutti, T., Remes, A., Rinne, J. \& Soininen, H. (toim.), Muistisairaudet (s. 35-43). Helsinki: Duodecim.

Vlakveld, W.P. \& Davidse, R.J. (2011). Effect van verhoging van de keuringsleeftijd op de verkeersveiligheid. SWOV Report R-2011-6. Haettu 1.11.2017 osoitteesta:

https://www.swov.nl/sites/default/files/publicaties/rapport/r-2011-06.pdf

Yhdenvertaisuuslaki 30.12.2014/1325. 